\title{
CELEBRATING 40 YEARS OF PROFESSOR BILL ATKIN
}

\author{
Judge Peter Boshier*
}

This article traces Bill Atkin's contribution to family law in New Zealand, with a particular focus on his commitment to law reform.

\section{INTRODUCTION}

Family law has a unique place in the New Zealand legal landscape. Due to the fact that it touches on so many aspects of life - from care of children to adoption, to our vulnerable elderly through to domestic violence, state involvement with at-risk children, and after-life issues of wills and estates - it has a very broad reach. By virtue of this broad application, and the fact that it often affects the lives of the most vulnerable in our society, it is absolutely vital that the system works well. Family law is made not only by the policy makers who dream it, the politicians who create it, the lawyers who practise it and the judges who decide it, but, crucially, by the academics who devote themselves to critiquing, improving and contributing to the law from their unique, independent perspective. Throughout my years as a Family Court Judge, there have been many occasions when I have been grateful for the diligent and critical contribution of the family law academics in New Zealand, of whom Bill Atkin is a key figure.

Fortunately for New Zealand, a young Bill Atkin decided to return from teaching at Bristol University to teach at Victoria University of Wellington in 1975. It suited him. Forty years later, it is time to celebrate the academic and legal career of Professor Bill Atkin, Professor of Family Law and the Law of Torts. It is easy to see why countless students adore Bill. He is personable, engaging and enthusiastic: he thrives when discussing ideas. For his part, Bill has said that he has been invigorated by the interaction with undergraduates and by his truly "team approach" to supervising graduates. I gather that it is this stimulation which has been one of the biggest factors in Bill's decision to stay in the academic world. Overall, his contribution to family law been immense and I welcome this opportunity to pay tribute to Bill.

* His Hon Judge Peter Boshier is currently a Law Commissioner. He was the Principal Family Court Judge from 2004-2012. Thanks to Julia Spelman, former research clerk (and former family law student of Bill's), for her comments on an early draft of this article. 
This article attempts to outline Bill's contribution to family law by considering the impact he has had both within and beyond academia, particularly in the area of law reform. Although we were at law school together, Bill was slightly ahead of me so it was not until I was appointed as a Family Court Judge in 1988 that we began to get to know each other. After I was appointed as the Principal Family Court Judge in 2004 we had much to do with each other. While others will be well placed to comment on his popularity as a lecturer, and his formidable academic record across both Family Law and the Law of Torts, my perspective is slightly different. For the last decade, eight years as the Principal Family Court Judge and two years as a Law Commissioner, I have been in a position to see the extent to which Bill's tireless work has shaped the law itself.

When Bill was asked by the then-Dean of the Law School at Victoria University, John Thomas, to return to teach, Bill was given a choice of either family or company law. This was because the iconic Professor Don Inglis had retired from teaching family law and the company law teaching slot was similarly vacant. How to choose? The reason Bill chose family law says something about his personality and the shape of his enduring career. He decided on family law because it was in that area that he saw human frailty as most evident and that he thought he might be able to help people the most. This motivation seems to have formed the basis for Bill's long career as he has positioned himself to contribute to the law in order to improve the lives of others.

\section{LAW REFORM}

The role that academics play in relation to parliamentary law reform is varied. Not all have the interest, and not all have the ability, to influence. It is rare to find an academic who is not only highly respected as a teacher and researcher, but whose advice is regularly sought and relied on by policy makers across the political spectrum. Throughout his career, Bill has kept a watching brief on family law reform and has frequently written, commented and appeared before government select committees. I want to touch on several of the areas that have benefited from Bill's expertise to highlight the breadth of his contribution.

Bill made submissions prior to the enactment of the Matrimonial Property Act 1976, and when major family law reforms occurred in 1980, he similarly commented on and made submissions in relation to the Family Proceedings Bill ${ }^{1}$ and the Family Courts Bill. ${ }^{2} \mathrm{He}$ also contributed to a report on Matrimonial Property and Family Protection as part of the Justice Department Working Group in $1988 .^{3}$

1 Family Proceedings Bill 1978 (144), enacted as the Family Proceedings Act 1980.

2 Family Courts Bill 1979 (143), enacted as the Family Courts Act 1980.

3 Report of the Working Group on Matrimonial Property and Family Protection (Department of Justice, 1988). 
In 1982 the Domestic Protection Act was passed and then in 1995 major domestic violence legislation followed. For Bill, the proposed 1982 Domestic Protection Bill had many shortcomings and, with two other Faculty members, he made extensive submissions on it. It is generally accepted that because of the flaws highlighted, significant redrafting of the legislation occurred before it became law. The Domestic Protection Act 1982, later replaced by the Domestic Violence Act 1995, was considered to be a significant step in addressing the major problem of domestic violence in New Zealand.

In 1993 and 1994 further assistance in law reform was sought from Bill by the then-Minister of Justice, the Hon Douglas Graham MP, on the issue of assisted reproduction technology. Bill was one of two members of the Ministerial Committee which reported to the Minister. The Human Assisted Reproductive Technologies Act 2004 very much reflected the outcome of Bill's earlier work.

The other very large focus of Bill's family law attention has been adoption law. Bill's first serious foray into the unfinished world of adoption reform and practice was in 1990 when the thenMinister of Social Welfare, the Hon Michael Cullen MP, set up the Ministerial Adoption Practices Review Committee, of which Bill was the Chair. A number of statutory reforms were suggested but sadly, nothing eventuated. At least one of the proposed reforms - more open adoption - was able to be achieved much more in practice, if not in law. While legislative change in the area of adoption law has not been forthcoming, Bill has steadfastly continued to raise awareness of the need to update the law, which is now 60 years' old. ${ }^{4}$

There are two other areas of legislation where Bill has had a close interest. The first was Sue Bradford's Private Member's Bill, which was drawn from the ballot in 2005..$^{5}$ This was a proposed amendment to s 59 of the Crimes Act 1961 to remove the defence of "reasonable force" when correcting a child. As is well known, this issue ignited enormous public debate in New Zealand and the parliamentary process was highly scrutinised. When the Law Commission was invited by the Chair of the Justice and Electoral Committee to advise the Committee on the Crimes (Abolition of Force as a Justification for Child Discipline) Amendment Bill, the Law Commission was authorised to consult with a select group. This group was limited to Sue Bradford MP, Chester Borrows MP, Professor Bill Atkin, the Office of the Clerk and the Parliamentary Counsel Office. ${ }^{6}$

Of course New Zealand has been through some dramatic times in terms of family law development more recently. Bill has made many submissions but I want to focus particularly on his

4 Adoption Act 1955.

5 Crimes (Abolition of Force as a Justification for Child Discipline) Amendment Bill 2005 (Member's Bill: Sue Bradford) (later the Crimes (Substituted Section 59) Amendment Bill 2005 (271)).

6 Law Commission Section 59 of the Crimes Act 1961 Amendment: Options for Consideration (NZLC OP3, 2006). 
work in relation to the marriage equality legislation, the Family Court reforms and the Vulnerable Children Bill. ${ }^{7}$

New Zealand's path to marriage equality passed a major hurdle in 2004 when the Civil Union Act 2004 became law, allowing homosexual and heterosexual couples to enter into civil unions. While some argued that this should be enough, the campaign for "full marriage equality" continued. Bill is regularly approached to provide commentary on legal issues and this issue was no different. When interviewed in 2011, Bill pointed out that civil union couples were not treated the same as married couples in relation to the Adoption Act 1955, as same-sex civil couples were prevented from adopting children. ${ }^{8}$ On the proposed marriage equality legislation, Bill worked with other members of the Law Faculty to produce a written submission to the Select Committee by 24 individual members of the Faculty of Law of Victoria University, with Bill Atkin and Claudia Geiringer acting as spokespeople. ${ }^{9}$ This submission, while helpfully assisting the Committee on a number of technical points, made the forceful argument that "it is, quite simply, unfair for a segment of the community to be denied access to a state-sponsored institution on the basis of their sexual orientation". ${ }^{10}$ The following year, Parliament passed the Marriage (Definition of Marriage) Amendment Act 2013 which clarified that marriage means "the union of 2 people, regardless of their sex, sexual orientation, or gender identity". ${ }^{11}$ Once the legislation was passed, Bill also enabled a wider audience to understand and benefit from the New Zealand experience in his writing and analysis in various publications. ${ }^{12}$

When it comes to the recent Family Court reforms, Bill's personal approach to this work is very important. His humility and ability to work well with many different groups means that his views and recommendations are listened to and taken on board. In an area where ego and politics have at times obscured the development of family law, Bill has remained a respected academic voice. This surely is an example of the importance of an independent academy, as Bill has been able to critique, improve and at times, rescue various policies and pieces of legislation. For many judges and family law practitioners, the Family Court reforms were a source of concern. As it is the legislature's constitutional role to enact legislation, it was not appropriate for the judiciary to engage in the process of policy development. At a time when tensions were high, it was of great comfort to many

$7 \quad$ Vulnerable Children Bill 2013 (150).

8 Selina Powell "Going to the Chapel" (15 August 2011) Salient <www.salient.org.nz>.

9 Certain individual members of the Faculty of Law, Victoria University of Wellington "Submission to the Government Administration Committee on the Marriage (Definition of Marriage) Amendment Bill 2012".

10 At 2 .

11 Marriage (Definition of Marriage) Act 2013, s 5.

12 Including Bill Atkin "Same-Sex Marriage and Family Law Reform in New Zealand" (10 May 2013) Jurist <www.jurist.org>. 
that Bill, and other academics, were scrutinising and submitting on the proposals. As usual, Bill was able to use his independence as an academic to bring rigour and accountability to his work, with the highest standards of professionalism, at a time when family law reform was politically charged.

Bill also acted as one of two spokespersons for the New Zealand Law Society in relation to its work on the Vulnerable Childrens Bill in $2013 .{ }^{13}$ Bill was able to acknowledge the admirable spirit of the proposed legislation and the potential benefits, while pointing out: "The Law Society has identified significant aspects of the bill that need to be strengthened in order for the bill to achieve its objective."14 The Vulnerable Children Act 2014 certainly had the benefit of the very detailed submissions made by the Law Society. ${ }^{15}$

\section{RESEARCH}

It is clear that one cannot have such a significant influence on law reform without having a watertight reputation as a leading academic who regularly produces high quality publications. Bill's research and writing has been prolific, especially in the field of family law, but also in torts, and it is this academic foundation that has allowed Bill to comment with authority on matters of law reform. When Bill commenced his career as an academic, Professor Tony Angelo became his mentor, and in what has been a long and very supportive academic relationship, Bill has said that the writing and research pathway that he has taken has the unmistakable stamp of Tony Angelo's wisdom, experience and support.

Bill has been a regular contributor to the Fisher looseleaf text on matrimonial property ${ }^{16}$ and also family law service publications, updating lawyers in particular with recent trends and decisions in family law. This work is particularly important as family law practitioners and judges have often found it difficult to access up-to-date family law cases due to difficulties with publication processes.

The family law service is, in my opinion, one of the most helpful texts available to judges. The reason? It is the currency and relevance of the law that means we can be more exact in our decision making. Family law moves rapidly, both legislatively and as a matter of case law. Sometimes judges will have differing interpretations on new law. While this settles in, having the ability to read what other colleagues have said and why, is one of those vital decision-making tools when there is the need to move speedily but accurately. And so, the contribution in this respect is one of the most important of all.

13 Vulnerable Children Bill 2013 (150).

14 New Zealand Law Society "Legislation to protect vulnerable children needs strengthening" (press release, 29 November 2013).

15 New Zealand Law Society "Submission to the Social Services Select Committee on the Vulnerable Children Bill 2013".

16 RL Fisher (ed) Fisher on Matrimonial and Relationship Property (online looseleaf ed, LexisNexis). 
He has also written extensively on relationship property, ${ }^{17}$ family law policy ${ }^{18}$ and social security law. ${ }^{19}$

There is a publication titled The International Survey of Family Law, and the object of that publication is an annual country-by-country analysis and update of family law. Bill has edited this since 2007 and the 2014 edition contained 29 chapters. I know he regards this as having been one of his greater challenges. Endeavouring to get the relevant country authors organised on time to ensure that developments are up to date has consumed a great deal of time and effort.

Within New Zealand, Bill is recognised as one of the leading authorities on family law. Family law practitioners and judges are fortunate to have the benefit of such expertise. For some time, Bill Atkin from Victoria University, Mark Henaghan from Otago University, John Caldwell from Canterbury University and Pauline Tapp from the University of Auckland have led the way with research and commentary in this area. One example of their recent work is the collaborative article "Fifty Years of New Zealand Family Law."20

\section{THE FUTURE}

What of the future? I doubt that Professor Atkin will contemplate any major change of direction. I sense that his love of teaching, interaction with the students and the enormous satisfaction he feels in that relationship is the most important of all. Working in an academic institution has all sorts of challenges, for instance the sometimes difficult relationship between autonomy and the increasingly demanding requirements of university bureaucracy. So for as long as Bill can continue to have his present diet of writing and researching, contributing to law reform and imparting knowledge to his students, I doubt that there will be any sudden end to this prolific academic career.

My personal reflection is this. As old-fashioned as the description may seem, I most like to describe Bill as a gentleman. He is measured and often self-effacing. His personality and ego rank behind his genuine interest in others and in the law. I am not surprised that he has been so used by various ministers in providing advice and that his work has been relied upon to the extent that it has. It is fitting that for a person as understated as Bill, I can say that his contribution has truly enriched New Zealand family law and practice and that would be the biggest understatement of all.

17 Bill Atkin and Wendy Parker Relationship Property in New Zealand (2nd ed, LexisNexis, Wellington, 2009); and Bill Atkin Living Together without Marriage: The Law in New Zealand (Butterworths, Wellington, 1991).

18 Bill Atkin and Mark Henaghan (eds) Family Law Policy in New Zealand (Oxford University Press, Auckland, 1992); most recently Bill Atkin and Mark Henaghan (eds) Family Law Policy in New Zealand (4th ed, LexisNexis, Wellington, 2013).

19 Bill Atkin "Social Security Law - New Zealand" in R Blanpain (ed) International Encyclopaedia of Laws (Kluwer Law International, The Hague, 2013) 164 (new edition due in 2015).

20 Bill Atkin and others "Fifty Years of New Zealand Family Law" (2013) 25 NZULR 645. 